\title{
Bobot Potong, Persentase Karkas Semu dan Index Konformasi Karkas Domba Lokal pada Penggemukan yang Diberi Pakan Berbasis Indigofera Sp.
}

\author{
Slaughter Weight, Apparent Carcass Percentage and Index of Conformation of Carcass of \\ Fattening Sheep Fed Based on Indigofera Sp.
}

\section{Agustinah Setyaningrum*, Pambudi Yuwono, Imbang Haryoko, Billy Trisdianto}

Fakultas Peternakan Universitas Jenderal Soedirman, Purwokerto
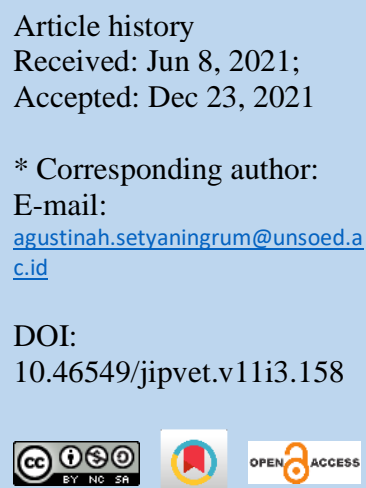

\section{Abstract}

The aims of this study were to examine the slaughter weight, the percentage of apparent carcasses and the conformation index of carcasses of local sheep fed indigofera sp. as a substitute for commercial concentrates with different levels. The research method was an experiment with a Completely Randomized Design (CRD). The experiment was in vivo in 18 sheep fed different level of indigofera $s p$, $\mathrm{P} 0$ treatment being a basal ration as a control consisting of concentrate $(\mathrm{K})$ and elephant grass $(\mathrm{RG})$ with a ratio of $80: 20 \%$. P1 was $40 \% \mathrm{~K}$ : 40\% indigofera: $20 \%$ RG, and P2 was 30\% K: 50\% indigofera: $20 \%$ RG. Each treament was repeated 6 times. Sheep were offered feed $4 \%$ of body weight on dry matter basis. slaughter weight data were analyzed using Ancova, SPSS program version 16 with initial body weight as covariate. Apparent carcass percentage data and carcass conformation index were analyzed with anava. The results of covariance analysis showed no significant difference $(P>0.05)$ amongst treatments. The average initial body weights of P0, P1 and P2 were $9.58 \pm 1.68$, $10.58 \pm 3.09$ and $9.28 \pm 1.91 \mathrm{~kg}$, respectively. after receiving treatment for 70 days the slaughter weights for P0, P1 and P2 were $15.57 \pm 3.64,13.58 \pm 2.76,12.58 \pm$ $1.65 \mathrm{~kg}$, respectively. The average consumption of dry matter for P0, P1 and P2 were $400.19 \mathrm{~g} / \mathrm{head} / \mathrm{day}, 401.20 \mathrm{~g} / \mathrm{head} / \mathrm{day}$ and $398.59 \mathrm{~g} / \mathrm{head} /$ day, repectively. The average percentage of apparent carcasses for $\mathrm{P} 0$ : $40.61 \pm 2.43 \%$; $\mathrm{P} 1: 34.33 \pm 0.63 \%$ and $\mathrm{P} 2: 34.03 \pm 4.61 \%$. Average carcass conformation index for $\mathrm{P} 0: 0.47 \pm 0.04$; P1: $0.43 \pm 0.01$ and $\mathrm{P} 2: 0.43 \pm 0.01$. Indigofera $\mathrm{sp}$ had no significant effect $(\mathrm{P}>0.05)$ on the percentage of apparent carcass and carcass conformation index. In Conclusion, indigofera sp. does not decrease local sheep productivity and can be used to replace concentrates as a source of protein.

Keywords: Apparent carcass percentage; Index of carcass conformation; Indigofera sp.; Local sheep; Slaughter weight.

\section{Abstrak}

Penelitian bertujuan mengkaji bobot potong, persentase karkas semu dan index konformasi karkas domba lokal yang diberi Indigofera sp. sebagai pengganti konsentrat komersial dengan level yang berbeda. Metode penelitian adalah eksperimental. Rancangan yang digunakan adalah Rancangan Acak Lengkap (RAL). Penelitian berlangsung secara in vivo pada domba sebanyak 18 ekor, dengan perlakuan $\mathrm{P0}$ adalah ransum basal sebagai kontrol yang terdiri dari konsentrat $(\mathrm{K})$ dan rumput gajah (RG) dengan perbandingan $80 \%: 20 \%$. P1 adalah 40\% K: $40 \%$ indigofera: $20 \% \mathrm{RG}$, dan P2 adalah $30 \% \mathrm{~K}: 50 \%$ indigofera: $20 \% \mathrm{RG}$. Masing 2 perlakuan diulang 6 kali. Pemberian pakan sebesar $4 \%$ bobot badan berdasarkan bahan kering. Data bobot potong dianalisis dengan Ancova, program SPSS versi 16 dengan bobot badan awal sebagai covariat. Data persentase karkas 
semu dan index konformasi karkas dianalisis dengan anava. Hasil analisis covariansi menunjukkan tidak berbeda nyata $(\mathrm{P}>0,05)$ antar perlakuan. Rataan bobot badan awal P0, P1 dan P2 masing-masing adalah 9,58 $\pm 1,68,10,58 \pm 3,09$ dan $9,28 \pm 1,91 \mathrm{~kg}$, setelah mendapatkan perlakuan selama 70 hari bobot potong untuk P0, P1 dan P2 berturut-turut $15,57 \pm 3,64,13,58 \pm 2,76$ dan $12,58 \pm 1,65 \mathrm{~kg}$. Rataan konsumsi bahan kering P0, P1 dan P2 berturut-turut adalah: 400,19g/ek/hr, $401,20 \mathrm{~g} / \mathrm{ek} / \mathrm{hr}$ dan 398,59g/ek/hr Rataan persentase karkas semu pada P0: $40,61 \pm 2,43 \%$, P1: $34,33 \pm 0,63 \%$ dan P2: 34,03 $\pm 4,61 \%$. Rataan index konformasi karkas untuk P0: $0,47 \pm 0,04, \mathrm{P} 1: 0,43 \pm 0,01$ dan $\mathrm{P} 2$ : $0,43 \pm 0,01$. Pemberian Indigofera sp tidak berpengaruh nyata $(\mathrm{P}>0,05)$ terhadap persentase karkas semu maupun index konformasi karkas. Kesimpulan Indigofera sp. tidak menurunkan produktivitas ternak domba lokal, dan dapat digunakan untuk menggantikan konsentrat sebagai bahan sumber protein.

Kata kunci: Bobot potong; Domba lokal; Index konformasi karkas; Indigofera sp.; Persentase karkas semu

\section{PENDAHULUAN}

Swasembada daging merupakan salah satu program nasional dalam produksi pangan yang harus mendapat dukungan serius untuk dapat direalisasikan. Usaha untuk meningkatkan mutu genetik dan populasi ternak domba lokal membutuhkan adanya manajemen reproduksi yang baik (Purwaningsih dan Sunardi, 2010), namun ternak domba lokql ekor tipis juga termasuk ternak unggul lokal penghasil daging yang tahan cekaman dan potensial untuk dibudidayakan, sehingga dengan pakan hijauan berkualitas diharapkan dapat menghasilkan produktivitas yang tinggi dan berkontribusi dalam swasembada daging nasional.

Tujuan akhir produksi ternak potong adalah menghasilkan karkas dengan produksi dan daging yang prima. Proporsi karkas dengan kandungan daging tinggi, maka tulang dan lemaknya akan lebih rendah. Variable index konformasi karkas menjadi penting, untuk mengetahui proporsi komponen karkas yang diinginkan.

Salah satu hijauan legume yang berpotensi untuk pakan ternak domba adalah Indigofera zollingeriana sebagai bahan pakan sumber protein karena memiliki kandungan protein kasar relative tinggi dibanding legume yang lain. Potensi indigofera sp diharapkan dapat menjadi bahan untuk substitusi konsentrat komersial. Hal ini mendukung peningkatan kualitas pakan domba yang sebagian besar di Indonesia masih mengandalkan hijauan alam. Hasil penelitian diharapkan dapat memberikan informasi tentang produktivitas ternak ruminansia kecil (domba ekor tipis) yang diberi hijauan pakan bermutu sebagai pengganti konsentrat.

\section{MATERI DAN METODE}

Penggemukkan domba ekor tipis jantan dilakukan secara intensif selama 70 hari. Metode yang digunakan adalah metode eksperimental dengan Rancangan Acak Lengkap. Materi menggunakan 18 domba ekor tipis jantan lepas sapih. Kandang individu lemprakan sebanyak 18 petak. Peralatan meliputi timbangan bobot badan, timbangan pakan dan sisa pakan, metline dan alat pemotongan ternak.

Ransum basal terdiri dari rumput Gajah dan konsentrat komersial sesuai kebutuhan NRC (1985). Air minum diberikan secara ad libitum. Hijauan yang digunakan adalah rumput gajah yang ditanam di experimental farm dan tersedia cukup banyak sehingga siap untuk penelitian domba sebanyak 18 ekor selama 70 hari. Konsentrat yang digunakan terdiri dari 37\% jagung kuning giling, 34\% dedak, $24 \%$ pollard, 4,5\% bungkil kelapa dan $0,5 \%$ mineral mix. Pakan perlakuan adalah substitusi konsentrat menggunakan indigofera sp.

Pakan perlakuan $\mathrm{P}$ ada 3 kombinasi pakan yaitu

P0: 20\% Rumput Gajah dan 80\% konsentrat komersial (kontrol)

P1 : 20\% Rumput Gajah, 40\% konsentrat komersial dan $40 \%$ Indigofera $s p$. 
P2 : 20\% Rumput Gajah, 30\% konsentrat komersial dan 50\% Indigofera $s p$.

Masing-masing kombinasi perlakuan diulang 6 kali. Data yang diperoleh ditabulasikan dan dianalisis dengan analisis covariansi (Ancova) dengan bobot badan awal sebagai kovariat.

Tabel 1. Hasil analisis proksimat bahan pakan penelitian

\begin{tabular}{lccccccc}
\hline Bahan pakan & $\begin{array}{c}\text { BK } \\
(\%)\end{array}$ & $\begin{array}{c}\text { PK } \\
(\%)\end{array}$ & $\begin{array}{c}\text { LK } \\
(\%)\end{array}$ & $\begin{array}{c}\text { SK } \\
(\%)\end{array}$ & $\begin{array}{c}\text { ABU } \\
(\%)\end{array}$ & $\begin{array}{c}\text { BETN } \\
(\%)\end{array}$ & $\begin{array}{c}\text { TDN } \\
(\%)\end{array}$ \\
\hline Rumput Gajah & 21,25 & 8,82 & 2,26 & 22,6 & 16,28 & 50,54 & 58,31 \\
Konsentrat & 87,34 & 10,6 & 7,4 & 7,12 & 3,98 & 68,82 & 68,9 \\
Indigofera $s p^{2}$ & 85,98 & 12,15 & 10,37 & 32,89 & 5,61 & 38,98 & 70,2 \\
\hline
\end{tabular}

Keterangan: ${ }^{1}$ Hasil analisis di Lab. Ilmu Nutrisi dan Makanan Ternak Fak.Peternakan Unsoed

${ }^{2}$ Daun dan tangkai dominan tangkai

Tabel 2. Komposisi dan kandungan nutrien bahan pakan penelitian rumput gajah dan konsentrat

\begin{tabular}{lccccccc}
\hline \multirow{2}{*}{ Bahan pakan } & \multirow{2}{*}{ Komposisi \% } & \multirow{2}{*}{ BK } & \multicolumn{5}{c}{ \%BK } \\
\cline { 3 - 7 } & & & PK & LK & SK & Abu & BETN \\
\hline Rumput gajah & 20 & 4,25 & 0,18 & 0,05 & 0,45 & 0,33 & 1,00 \\
Konsentrat (P0) & 80 & 69,87 & 8,48 & 5,96 & 5,70 & 3,18 & 55,06 \\
Jumlah & 100 & 74,12 & 8,66 & 6,01 & 6,15 & 3,51 & 56,06 \\
\hline
\end{tabular}

Keterangan: Hasil analisis di Lab. Ilmu Nutrisi dan Makanan Ternak, Fak. Peternakan Unsoed.

Tabel 3. Kandungan nutrien ransum penelitian

\begin{tabular}{lccc}
\hline \multicolumn{1}{c}{ Bahan } & P0 & P1 & P2 \\
\hline Rumput Gajah : & & & 4,25 \\
\hline BK & 4,25 & 4,25 & 0,18 \\
PK (\%BK) & 0,18 & 0,18 & 0,05 \\
LK (\%BK) & 0,05 & 0,05 & 0,45 \\
SK $(\%$ BK) & 0,45 & 0,45 & 1,00 \\
BETN & 1,00 & 1,00 & \\
\hline Konsentrat : & & & 69,19 \\
\hline BK & 69,87 & 69,33 & 9,26 \\
\hline PK $(\%$ BK) & 8,48 & 9,10 & \\
\hline
\end{tabular}

Kandang disucihamakan terlebih dahulu sebelum digunakan untuk penelitian. Domba secara acak ditempatkan pada 18 unit kandang. Percobaan dilaksanakan selama 10 minggu atau 70 hari. Pakan diberikan sebanyak $4 \%$ dari bobot badan ternak berdasarkan bahan kering. Jadwal pemberian pakan adalah 3 kali sehari yaitu: pukul 07.00 pemberian konsentrat dan air minum, pukul 10.00 pemberian hijauan dan pukul 16.00 pemberian konsentrat dan hijauan. Domba ditimbang seminggu sekali untuk menyesuaikan jumlah ransum yang diberikan selanjutnya.

Pemotongan ternak seperti pada penelitian Setyaningrum dkk (2015), dimulai dengan memotong leher hingga vena jugularis, oesophagus, dan trachea terputus agar terjadi pengeluaran darah yang sempurna. Ujung oesophagus diikat agar cairan rumen tidak keluar apabila ternak digantung. Kepala dilepaskan dari tubuh pada sendi occipitoatlantis. Kaki depan dan kaki belakang dilepaskan pada sendi carpo-metacarpal dan sendi tendo-achiles pada kedua kaki belakang, kemudian kulitnya dilepas. Karkas segar diperoleh setelah semua organ tubuh bagian dalam dikeluarkan, yaitu alat reproduksi, hati, limpa, jantung, paru-paru, trachea, alat pencernaan, empedu dan pancreas, kecuali ginjal.

Peubah respon yang diamati dan diukur adalah: Bobot Potong: bobot ternak yang akan 
dipotong sesaat sebelum dipotong $(\mathrm{kg})$. Persentase karkas semu adalah perbandingan bobot karkas dibanding bobot potong (tanpa menguragi isi jeroan) dikalikan $100 \%$. Index konformasi karkas yaitu perbandingan lebar karkas dan panjang karkas

Lokasi Penelitian. Penggemukkan domba dilakukan di kandang D Experimental Farm Fakultas Peternakan Unsoed. Pemotongan ternak dilakukan di ruang kelas experimental farm Fakultas Peternakan Unsoed.
HASIL DAN PEMBAHASAN

\section{BOBOT POTONG}

Hasil analisis covariansi menunjukkan bahwa rataan bobot potong domba untuk semua perlakuan dalam kisaran 12,58 $\pm 1,65$ sampai $15,57 \pm 3,64 \mathrm{~kg}$, seperti tersaji pada Tabel 4 . Bobot awal domba penelitian dalam kisaran $9,28 \pm 1,91$ sampai $10,58 \pm 3,09 \mathrm{~kg}$.

Tabel 4. Rataan bobot awal dan bobot potong domba dengan pakan konsentrat disubstitusi Indigofera $s p$.

\begin{tabular}{ccc}
\hline Perlakuan & Bobot awal $(\mathrm{kg})$ & Bobot Potong $(\mathrm{kg})$ \\
\hline P0 & $9,58 \pm 1,68^{\mathrm{a}}$ & $15,57 \pm 3,64^{\mathrm{b}}$ \\
P1 & $10,58 \pm 3,09^{\mathrm{a}}$ & $13,58 \pm 2,76^{\mathrm{b}}$ \\
P2 & $9,28 \pm 1,91^{\mathrm{a}}$ & $12,58 \pm 1,65^{\mathrm{b}}$ \\
\hline
\end{tabular}

Superskrip yang sama pada baris yang berbeda menunjukkan pengaruh tidak nyata

Hasil analisis covariansi menunjukkan bahwa bobot awal tidak berpengaruh nyata terhadap bobot potong $(\mathrm{P}>0,05)$. Substitusi indigofera $s p$ berpengaruh tidak nyata terhadap bobot potong $(\mathrm{P}>0,05)$. Hal tersebut membuktikan bahwa substitusi konsentrat dengan indigofera sp sampai pada level $50 \%$ dalam konsentrat tidak berbeda dengan pakan tanpa indigofera $s p$. Pemberian indigofera $s p$. dapat menggantikan konsentrat karena tidak menunjukkan penurunan bobot potong atau penurunan performan ternak. Penggantian konsentrat dengan indigofera $s p$ menjadi informasi sangat penting, karena secara ekonomi lebih murah, dan keterjangkauannya lebih mudah. Indigofera $s p$ dapat ditanam atau dibudidayakan secara besar-besaran untuk menggantikan konsentrat (konsentrat hijau) di wilayah peternakan ruminansia yang tergolong peternakan rakyat yang semua ternaknya hanya mengandalkan alam. Substitusi konsentrat dengan indigofera sp dapat dilakukan karena mempunyai kandungan nutrient yang relative sama, terutama protein kasar. Penelitian ini menggunakan indigofera $s p$ dengan komposisi bagian tanaman daun dan tangkai dominan tangkai. Dengan kandungan protein kasar
12,15\%. Abdullah (2011) menyatakan bahwa indigofera $s p$ dapat mengandung protein kasar sampai $24,3 \%$. Perbedaan kandungan protein kasar diakibatkan perbedaan komponen tanaman yang digunakan untuk pakan ternak. Penggunaan daun tangkai dominan daun mengakibatkan protein kasar lebih tinggi disbanding daun dan tangkai dominan tangkai. Akbarillah et al. (2010) melaporkan nilai nutrisi tepung daun indigofera adalah sebagai berikut: protein kasar $27.97 \%$; serat kasar $15.25 \%$, Ca $0.22 \%$ dan P $0.18 \%$. Tanaman Indigofera sp. dapat diolah menjadi tepung. Disebutkan bahwa sebagai sumber protein, tepung daun Indigofera mengandung pigmen yang cukup tinggi seperti xantofil dan carotenoid.

Setyaningrum et al. (2019) menyatakan bahwa substitusi konsentrat komersial dengan indigofera $\mathrm{sp}$ menunjukkan bahwa level indigofera $\mathrm{sp} 62,5 \%$ dari ransum yang diberikan menyebabkan konsumsi bahan kering paling rendah yaitu $398,59 \mathrm{~g} / \mathrm{ek} / \mathrm{hr}$ namun pertambahan bobot badan harian tidak berbeda nyata. Hal tersebut menunjukkan bahwa domba lebih efisien dalam mengkonsumsi indigofera sp sebagai konsentrat hijau. 


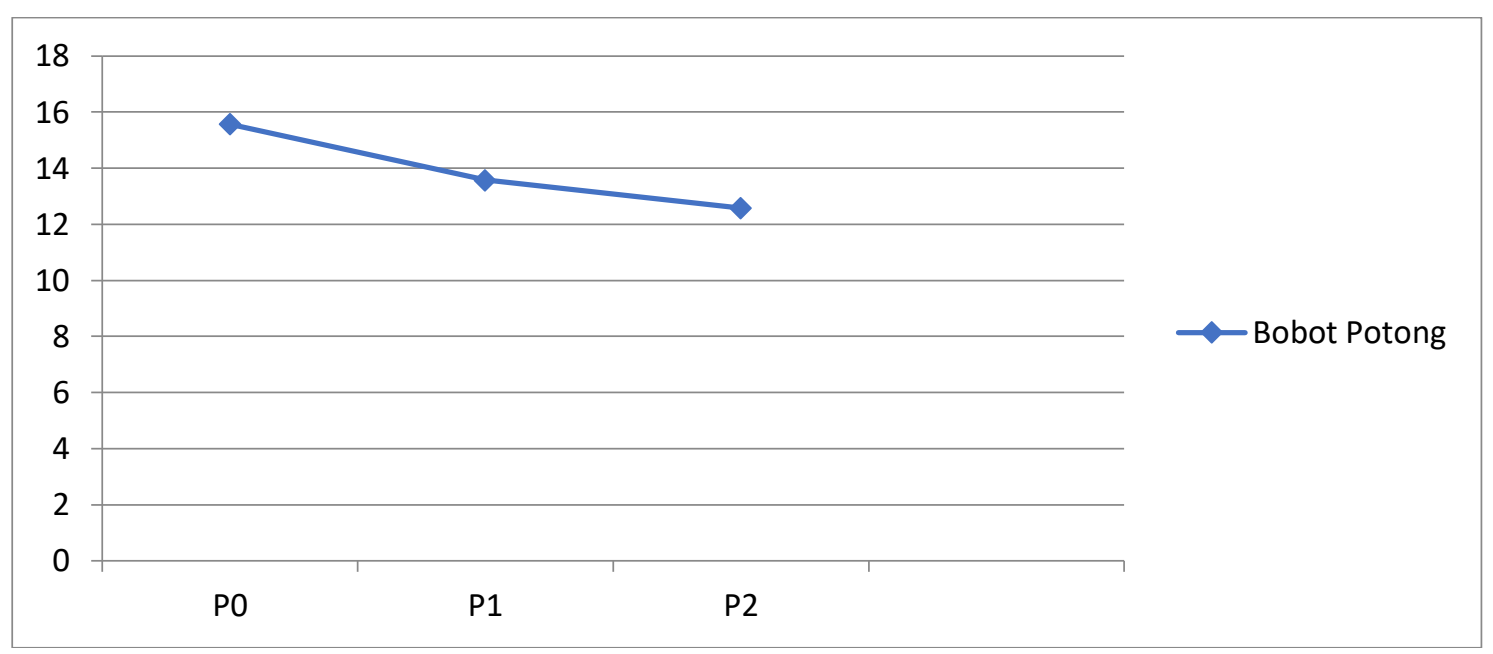

Gambar 1. Rataan bobot potong domba ekor tipis dengan pakan berbasis indigofera sp.

\section{PERSENTASE KARKAS SEMU DAN INDEX KONFORMASI KARKAS}

Hasil penelitian menunjukkan bahwa persentase karkas semu domba dengan pakan basal dan substitusi konsentrat dengan indigofera $s p$ dalam kisaran 34,03 $\pm 4,61 \%$ sampai $40,61 \pm 2,43 \%$ seperti tersaji pada Tabel 5. Index konformasikarkas untuk semua perlakuan dalam kisaran $0,43 \pm 0,01$ sampai $0,47 \pm 0,04$. Index konformasi karkas diperoleh dari hasil perhitungan lebar karkas dibanding panjang karkas. Perbandingan tersebut menunjukkan bahwa pada panjang karkas yang sama namun index konformasi karkas diperoleh lebih tinggi maka karkas lebih baik karena mempunyai ukuran lebih lebar. Hal ini menunjukkan bahwa ternak lebih gemuk.

Tabel 5. Rataan persentase karkas semu domba yang diberi pakan berbasis Indigofera Sp

\begin{tabular}{ccc}
\hline Perlakuan & Persentase karkas semu $(\%)$ & Index konformasi karkas \\
\hline P0 & $40,61 \pm 2,43^{\mathrm{a}}$ & $0,47 \pm 0,04^{\mathrm{b}}$ \\
P1 & $34,33 \pm 0,63^{\mathrm{a}}$ & $0,43 \pm 0,01^{\mathrm{b}}$ \\
P2 & $34,03 \pm 4,61^{\mathrm{a}}$ & $0,43 \pm 0,01^{\mathrm{b}}$ \\
\hline
\end{tabular}

Superskrip yang sama pada baris yang berbeda menunjukkan pengaruh tidak nyata $(\mathrm{P}>0,05)$

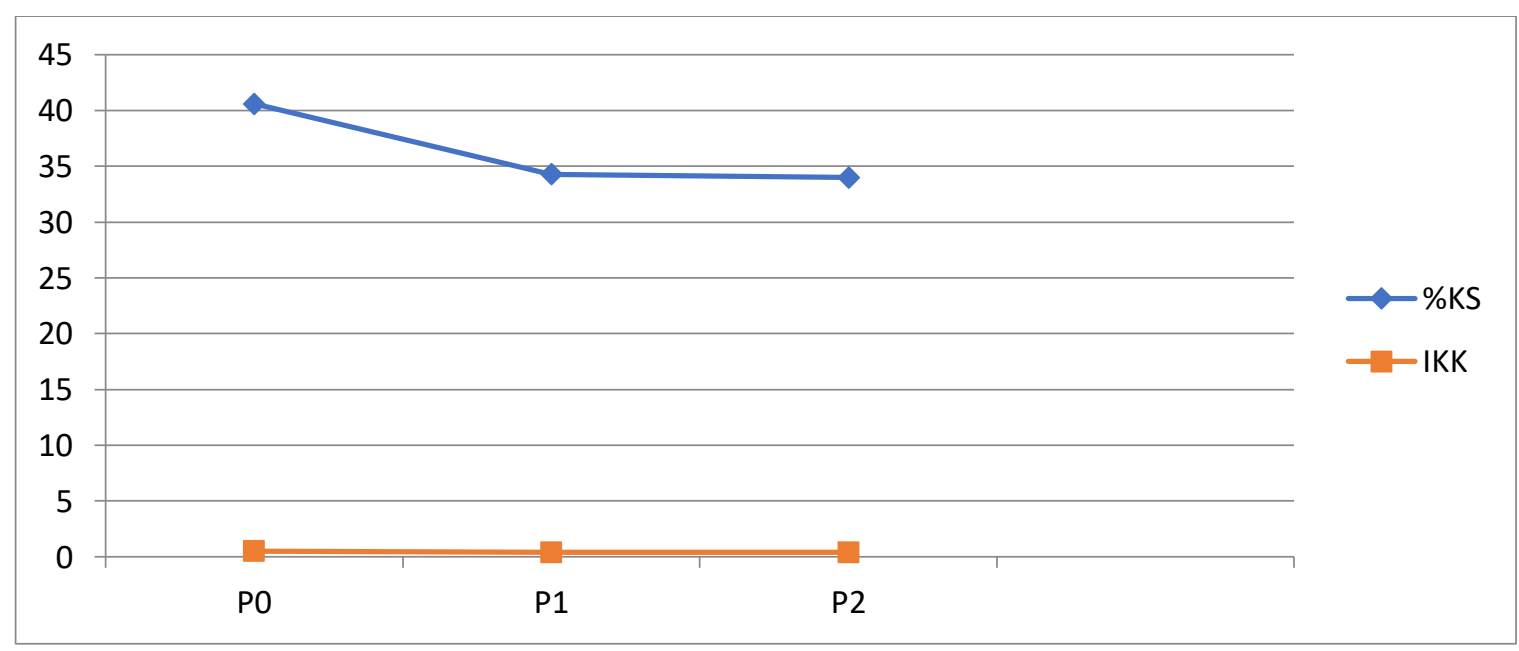

Keterangan: KS: Karkas Semu; IKK: Index Konformasi Karkas

Gambar 2. Rataan persentase karkas semu dan index konformasi karkas 
Pemberian Indigofera sp untuk mensubstitusi konsentrat tidak berpengaruh nyata $(\mathrm{P}>0,05)$ terhadap persentase karkas semu maupun index konformasi karkas. Substitusi indigofera sp sampai 50\% dalam konsentrat atau $62,5 \%$ dari total ransum masih dapat dilakukan. Pengaruhnya terhadap peubah sebelum dipotong maupun setelah dipotong sama saja, tidak menunjukkan performan yang menurun. Peternakan rakyat yang sangat mengandalkan hijauan pakan ternak perlu upaya peningkatan kualitas hijauan. Indigofera $s p$ dapat disarankan dibudidayakan untuk peternak ruminansia.

Konformasi karkas adalah salah satu karakteristik karkas atau kriteria penilaian karkas secara subyektif Saka et al. (2011), namun dapat menggambarkan prediksi penilaian karkas secara obyektif seperti prediksi komponen perdagingan atau index perdagingan. Tingginya index konformasi karkas masih dipengaruhi oleh factor lain termasuk panjang karkas.

\section{KESIMPULAN}

Indigofera $s p$. dengan komponen daun tangkai dominan tangkai tidak menurunkan produktivitas ternak domba lokal, dan dapat digunakan untuk menggantikan konsentrat sebagai bahan sumber protein. Komponen daun dan tangkai dominan tangkai dapat menggantikan $50 \%$ dalam konsentrat atau $62,5 \%$ dari ransum. Disarankan perlunya penelitian dengan komponen daun dan tangkai dominan daun dengan kandungan protein kasar yang lebih tinggi.

\section{UCAPAN TERIMA KASIH}

Ucapan terimakasih kepada Universitas Jenderal Soedirman yang telah mendanaii penelitian melalui dana BLU.

\section{DAFTAR PUSTAKA}

Abdullah L. 2011. Herbage production and quality of shrub indigofera sp. Treated by different concentration of foliar fertilizer. Media Peternakan (32): 169-175.

Akbarillah T, Kaharudin D dan Kusisiyah. 2012. Kajian tepung dalam indigofera $s p$. sebagai suplemen pakan terhadap produksi dan kualitas telur. Universitas Bengkulu. Bengkulu.

National Research Council. 1985. Nutrient Requirement of Sheep. 6th Edition, National Academy Press, Washington DC.

Purwaningsih dan Sunardi. 2010. Efektivitas Berbagai Waktu Injeksi PGF2 $\alpha$ Sebelum Penampungan Sperma Domba Lokal terhadap Kualitas Sperma dalam Pengencer Trisyang Disimpan Pada Suhu $50^{\circ} \mathrm{C}$. Jurnal Ilmu Peternakan, Vol. 5No.1ISSN 1907-2821, hal. 60-66.

Saka IK, Mantra IB, Ariana INT, Oka AA, Ni L. Sriyani P dan Sentana-Putra. 2011. Karakteristik karkas sapi bali betina dan jantan yang dipotong rumah potong umum Pesanggaran, Denpasar. The Excellence Research Universitas Udayana. pp. 39-47.

Setyaningrum A, Soeparno LM, Yusiati dan Kustantinah. 2015. Performance and Meat Quality of Thin Tailed Sheep in Supplementary Feeding Lemuru Fish Oil Protected by Saponification with Different $\mathrm{NaOH}$ Concentration. Journal Animal $\begin{array}{llll}\text { Production } & \text { Vol } 17 & \text { (3) } 177-185 \text {, }\end{array}$ Accredited by DGHE No. 81/DIKTI/Kep./2011. ISSN 1411-2027

Setyaningrum A, Suparman P, Haryoko I dan Priyono A. 2019. konsumsi pakan dan pertumbuhan domba lokal pada penggemukan dengan pakan berbasis indigofera sp. Abstrak. Seminar Nasional. LPPM Unsoed. Purwokerto. 